\title{
Heck and Sonogashira couplings in aqueous media - application to unprotected nucleosides and nucleotides
}

\author{
Gwénaëlle Hervé ${ }^{\text {and }}$ Christophe Len ${ }^{1,2^{*}}$
}

\begin{abstract}
Amongst all synthetic nucleosides having high potential biological activities, C5-modified pyrimidines and C7-deaza or C8-modified purines have been particularly studied. These main chemical modifications have been developed using palladium cross-coupling reactions. This review focus on both Heck and Sonogashira cross-coupling of nucleosides using different aspects of the twelve principles of green chemistry: use of aqueous medium and no protection/deprotection steps.
\end{abstract}

Keywords: Heck, Sonogashira, Green chemistry, Water

Nucleoside analogues having modifications of the glycone moiety [1-3] (eg AZT [4]) and/or the nucleobase [5-7] (eg BVDU [8,9]) are of great biological importance due to their high effectiveness as antiviral and antitumor agents. Among all the potent modifications, introduction of aryl, polyaryl, heteroaryl, heteropolyaryl, alkenyl and alkynyl groups on either the pyrimidine or the purine moiety via $\mathrm{C}-\mathrm{C}$ cross-coupling was described for the study of biological environments such as DNA and RNA structural probes, protein-DNA complexes, DNA damage, mutation and cancers $[10,11]$. The most efficient $\mathrm{C}-\mathrm{C}$ cross-coupling strategies are the palladium-catalyzed reactions such as (i) Suzuki-Miyaura, Stille, Negishi and Hiyama reactions for the formation of aromatic $\mathrm{C} \mathrm{sp}{ }^{2}-\mathrm{C}$ $\mathrm{sp}^{2}$; (ii) Heck reaction for the formation of vinyl derivatives and (iii) Sonogashira reaction for the formation of acetylenyl derivatives. These cross-coupling reactions were realized most often in organic solvents with protected nucleoside analogues. In order to use safer solvents and auxiliaries, to limit the risks and hazards, different groups have reported recently those cross-couplings in greener solvents such as water without the need for protection and deprotection steps. Since recent developments and a

\footnotetext{
* Correspondence: christophe.len@utc.fr

'Université de Technologie de Compiègne, Ecole Supérieure de Chimie Organique et Minérale, EA4297, Centre de recherche de Royallieu, BP20529, F-60205 Compiègne Cedex, France

${ }^{2}$ Department of Chemistry, University of Hull, England HU6 7RX, UK
}

complete review on Suzuki-Miyaura reaction applied to unprotected nucleosides were reported by our group [7,12-15], this paper will focused on the Heck reactions and Sonogashira reactions applied to unprotected nucleosides and nucleotides in aqueous media or water as sole solvent. For the sake of clarity, this review has been arranged to describe the Heck reaction and then the Sonogashira reaction. For each part, the different methodologies by varying the palladium source and nature with respect to $\operatorname{Pd}(0)$ and $\operatorname{Pd}(\mathrm{II})$, the nature of the base will be discussed.

\section{Heck cross-coupling}

Heck cross-coupling reaction in aqueous solution was developed using only $\mathrm{Pd}(\mathrm{II})$ as a pre-catalyst in water and in $\mathrm{CH}_{3} \mathrm{CN} / \mathrm{H}_{2} \mathrm{O}$.

The first Heck cross-coupling reaction starting from deprotected nucleoside was reported in 1998 by Barbas et al. [16]. Starting from 5-iodo-2'-deoxyuridine (1) and allyl amide 2 in presence of $\mathrm{Na}_{2} \mathrm{PdCl}_{4}(80 \mathrm{~mol} \%)$ as palladium source in sodium acetate buffer $(0.1 \mathrm{M}, \mathrm{pH}=5.2)$ as solvent at room temperature for 18 hours, $(E)$-[3(trifluoroacetamido)propenyl]-2'-deoxyuridine (3) was isolated in $44 \%$ yield (Scheme 1). Compound 3 is a precursor of functionalized dUTP derivatives that are substrates for thermostable DNA polymerases. $\mathrm{Nu}$ cleoside analogue 3 was obtained a few years later in 


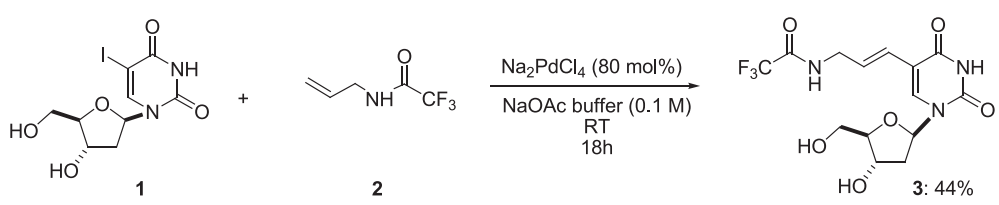

Scheme 1 Synthesis of nucleoside analogue 3.

the same range of yields by Williams et al. using the same experimental conditions [17].

\section{Pd(II)-catalyzed Heck cross-coupling in $\mathrm{CH}_{3} \mathrm{CN} / \mathrm{H}_{2} \mathrm{O}$}

More than a decade later, Shaughnessy et al. reported the first aqueous-phase Heck coupling of 5-iodo-2'deoxyuridine (1) under phosphine-free conditions [18]. After a classical optimization between iodo derivative 1 and butyl acrylate (4), best results were obtained using $\mathrm{Pd}(\mathrm{OAc})_{2}$ (5 mol\%) alone or in combination with water soluble TPPTS (10 mol\%) in presence of $\mathrm{Et}_{3} \mathrm{~N}$ (2 eq) as base in $\mathrm{CH}_{3} \mathrm{CN} / \mathrm{H}_{2} \mathrm{O}(2: 1)$ as solvent at $80^{\circ} \mathrm{C}$. Authors extended their optimized conditions to the coupling of cyclohexenone (5) and styrene (6) (Table 1).

Coupling of nucleoside analogue $\mathbf{1}$ with butyl acrylate (4) in the absence of ligand gave the target product 7 in
$64 \%$ yield, while a higher yield (74\%) was achieved when TPPTS (10 mol\%) was used (Table 1 , entries 1 and 2). Cyclohexenone (5) and styrene (6) were coupled with iodo derivative 1 , under ligand free conditions, to afford 8 and 9 in $72 \%$ and $82 \%$ yields, respectively (Table 1, entries 3 and 5). These yields were similar to those achieved when TPPTS (10 mol\%) was used (Table 1, entries 4 and 6). Aromatic styrene (6) gave higher yields than those obtained with alkenes 4 and 5 . Based on these results, Heck couplings of 5-bromo-2'-deoxyuridine as pyrimidine analogue, 8-bromo-2'-deoxyguanosine and 8-bromo-2'-deoxyadenosine as purine analogues were explored but without success.

Recently, Hocek et al. described the preparation of target acrylated-modified nucleotide analogues for polymerase synthesis of acrylate-labeled DNA. In this light, a

\section{Table 1 Synthesis of 5-vinyl nucleoside analogues 7-9}
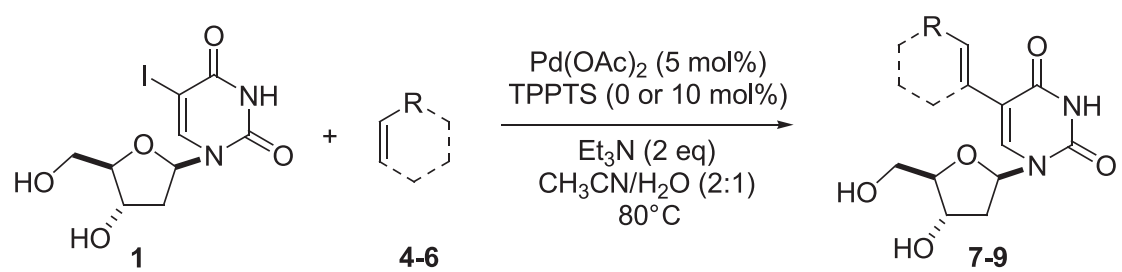

\begin{tabular}{lllll}
\hline Entry & Alkene & Ligand & Yield (\%) \\
\hline 1 & a & \\
2 & & &
\end{tabular}


Table 2 Synthesis of butyl acrylate uridine and cytosine analogues 7, 15-19

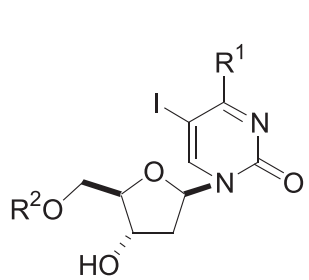

$1\left(\mathrm{R}^{1}=\mathrm{OH}, \mathrm{R}^{2}=\mathrm{H}\right)$

$\mathrm{BuCO}_{2} \mathrm{CHCH}_{2}$ (6 or $\left.10 \mathrm{eq}\right)$

$\mathrm{Pd}(\mathrm{OAc})_{2}$ (5 or $10 \mathrm{~mol} \%$ )

TPPTS (10 or $25 \mathrm{~mol} \%$ )

$\mathrm{NEt}_{3}(2$ or $3 \mathrm{eq})$

$\mathrm{CH}_{3} \mathrm{CN} / \mathrm{H}_{2} \mathrm{O}(1: 1)$

$80^{\circ} \mathrm{C}$

$1 \mathrm{~h}$ or $1.5 \mathrm{~h}$

$10\left(\mathrm{R}^{1}=\mathrm{OH}, \mathrm{R}^{2}=\mathrm{PO}_{3} \mathrm{H}_{2}\right)$

$11\left(\mathrm{R}^{1}=\mathrm{OH}, \mathrm{R}^{2}=\mathrm{P}_{3} \mathrm{O}_{9} \mathrm{H}_{4}\right)$

$12\left(\mathrm{R}^{1}=\mathrm{NH}_{2}, \mathrm{R}^{2}=\mathrm{H}\right)$

$13\left(\mathrm{R}^{1}=\mathrm{NH}_{2}, \mathrm{R}^{2}=\mathrm{PO}_{3} \mathrm{H}_{2}\right)$

$14\left(\mathrm{R}^{1}=\mathrm{NH}_{2}, \mathrm{R}^{2}=\mathrm{P}_{3} \mathrm{O}_{9} \mathrm{H}_{4}\right)$

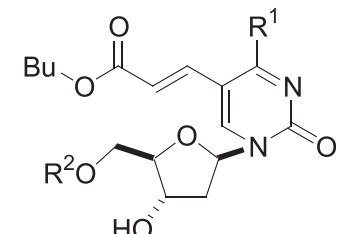

7, 15-19

\begin{tabular}{llllll}
\hline Entry & $\mathbf{R}^{\mathbf{1}}$ & $\mathbf{R}^{\mathbf{2}}$ & Starting material & Product & Yield (\%) \\
\hline 1 & $\mathrm{OH}$ & $\mathrm{H}$ & 1 & 7 & $98^{\mathrm{a}}$ \\
2 & $\mathrm{OH}$ & $\mathrm{PO}_{3} \mathrm{H}_{2}$ & 10 & 15 & $35^{\mathrm{b}}$ \\
3 & $\mathrm{P}_{3} \mathrm{O}_{9} \mathrm{H}_{4}$ & 11 & 16 & $4^{\mathrm{b}}$ \\
4 & $\mathrm{OH}$ & 12 & 17 & $16^{\mathrm{a}}$ \\
5 & $\mathrm{NH}_{2}$ & $\mathrm{PO}_{3} \mathrm{H}_{2}$ & 13 & 18 & $-{ }^{\mathrm{b}}$ \\
6 & $\mathrm{NH}_{2}$ & $\mathrm{P}_{3} \mathrm{O}_{9} \mathrm{H}_{4}$ & 14 & 19 & $-{ }^{\mathrm{b}}$ \\
\hline
\end{tabular}

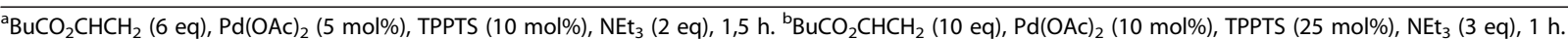

Table 3 Synthesis of butyl acrylate 7-deaza purine analogues 26-31

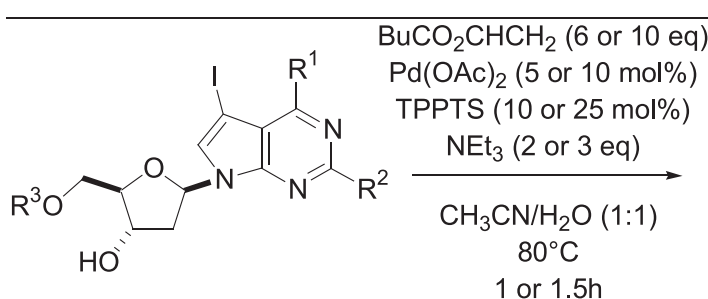

$20\left(R^{1}=\mathrm{NH}_{2}, \mathrm{R}^{2}=\mathrm{H}, \mathrm{R}^{3}=\mathrm{H}\right)$

$21\left(R^{1}=\mathrm{NH}_{2}, \mathrm{R}^{2}=\mathrm{H}, \mathrm{R}^{3}=\mathrm{PO}_{3} \mathrm{H}_{2}\right)$

$22\left(\mathrm{R}^{1}=\mathrm{NH}_{2}, \mathrm{R}^{2}=\mathrm{H}, \mathrm{R}^{3}=\mathrm{P}_{3} \mathrm{O}_{9} \mathrm{H}_{4}\right)$

$23\left(\mathrm{R}^{1}=\mathrm{OH}, \mathrm{R}^{2}=\mathrm{NH}_{2}, \mathrm{R}^{3}=\mathrm{H}\right)$

$24\left(\mathrm{R}^{1}=\mathrm{OH}, \mathrm{R}^{2}=\mathrm{NH}_{2}, \mathrm{R}^{3}=\mathrm{PO}_{3} \mathrm{H}_{2}\right)$

$25\left(\mathrm{R}^{1}=\mathrm{OH}, \mathrm{R}^{2}=\mathrm{NH}_{2}, \mathrm{R}^{3}=\mathrm{P}_{3} \mathrm{O}_{9} \mathrm{H}_{4}\right)$

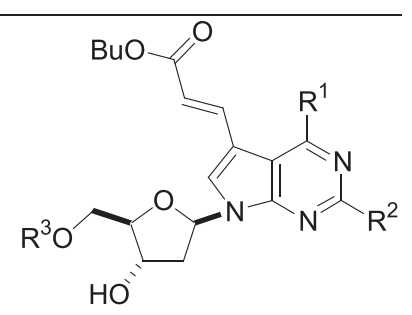

26-31

\begin{tabular}{lllllll}
\hline Entry & $\mathbf{R}^{\mathbf{1}}$ & $\mathbf{R}^{\mathbf{2}}$ & $\mathbf{R}^{\mathbf{3}}$ & Starting Material & Product & Yield (\%) \\
\hline 1 & $\mathrm{NH}_{2}$ & $\mathrm{H}$ & $\mathrm{H}$ & 20 & 26 & 27 \\
2 & $\mathrm{H}$ & $\mathrm{PO}_{3} \mathrm{H}_{2}$ & 21 & 28 & $55^{\mathrm{b}}$ \\
3 & $\mathrm{NH}_{2}$ & $\mathrm{H}$ & $\mathrm{P}_{3} \mathrm{O}_{9} \mathrm{H}_{4}$ & 22 & 29 & $43^{\mathrm{b}}$ \\
4 & $\mathrm{NH}_{2}$ & $\mathrm{NH}_{2}$ & $\mathrm{H}$ & 23 & 30 & $84^{\mathrm{a}}$ \\
5 & $\mathrm{OH}$ & $\mathrm{NH}_{2}$ & $\mathrm{PO}_{3} \mathrm{H}_{2}$ & 24 & 31 & $38^{\mathrm{b}}$ \\
6 & $\mathrm{OH}$ & $\mathrm{NH}_{2}$ & $\mathrm{P}_{3} \mathrm{O}_{9} \mathrm{H}_{4}$ & 25 & $44^{\mathrm{b}}$ \\
\hline
\end{tabular}

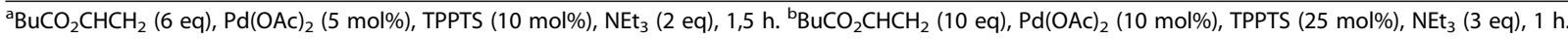


Table 4 Synthesis of various 5-acrylate-2'-deoxuridine analogues 7, 41-49

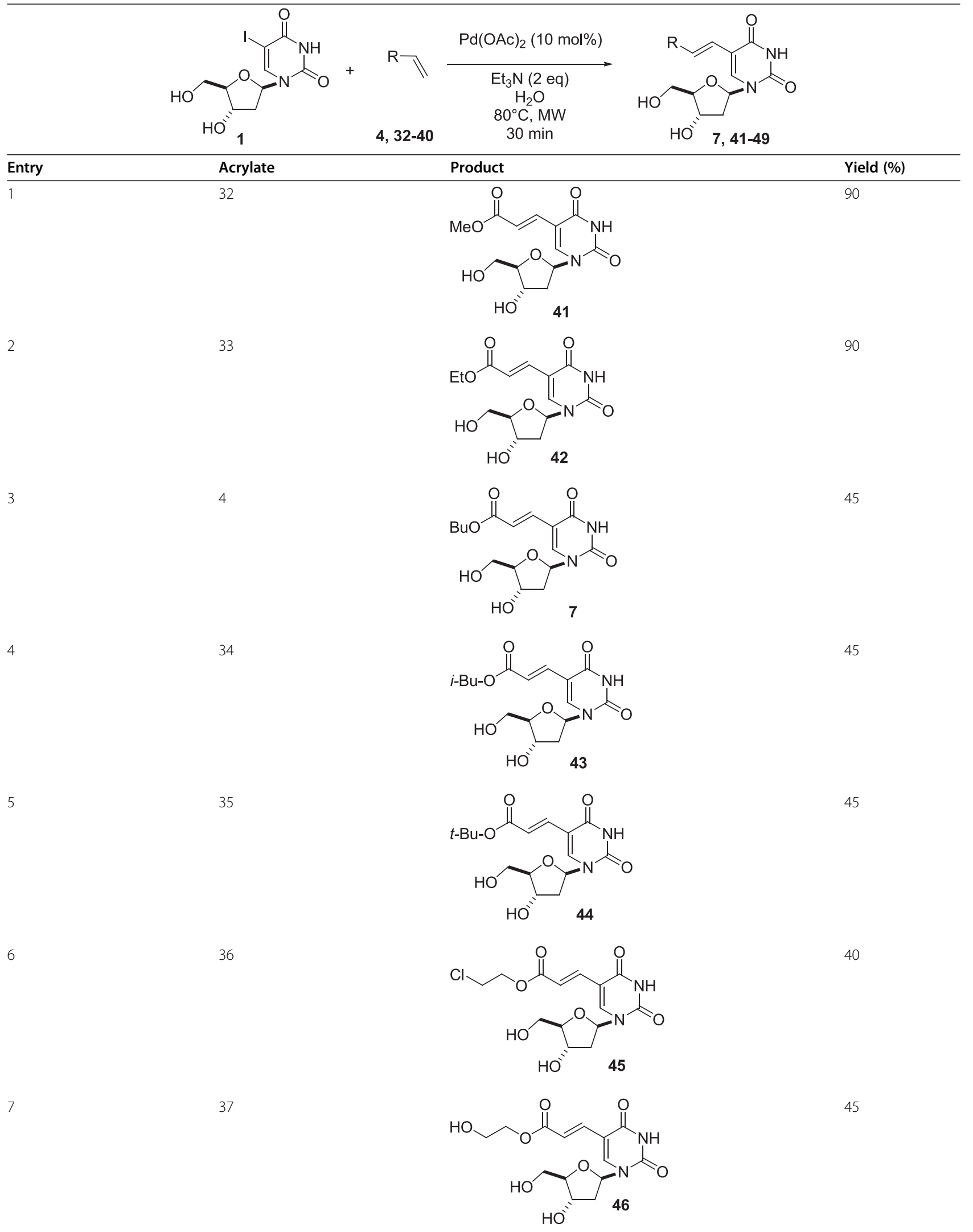


Table 4 Synthesis of various 5-acrylate-2'-deoxuridine analogues 7, 41-49 (Continued)

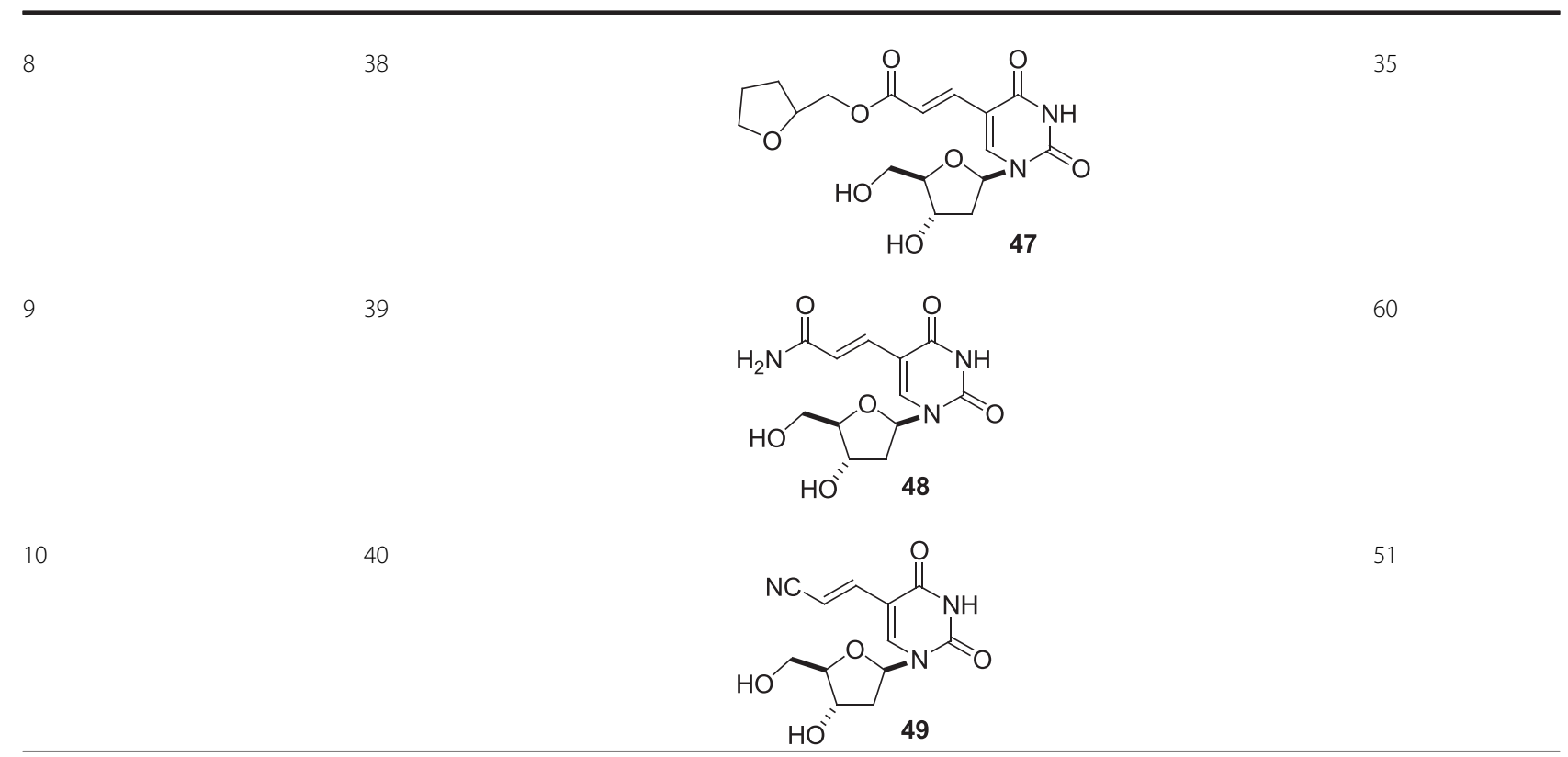

methodology for direct attachment of butyl acrylate (4) to various deoxyribonucleosides and their corresponding 5'-O-monophosphate (dNMPs) and 5'-O-triphosphate (dNTPs) derivatives was reported using the same catalytic promoter $\left(\mathrm{Pd}(\mathrm{OAc})_{2}\right.$ and $\left.\mathrm{TPPTS}\right)$, in presence of $\mathrm{NEt}_{3}$ as base in $\mathrm{CH}_{3} \mathrm{CN} / \mathrm{H}_{2} \mathrm{O}(1: 1)$ mixture as solvent [19]. In order to minimize hydrolysis of the phosphate group, higher amounts of acrylate 4 (10 eq vs 6 eq), catalyst (10 mol\% vs $5 \mathrm{~mol} \%$ ) and base (3 eq vs 2 eq) were used for the couplings of dNMPs and dNTPs compared to the couplings of the corresponding nucleosides but the reaction times were shorter. Heck couplings on nucleoside analogue 1 proceeded with good isolated yield $(98 \%)$ of modified nucleoside 7 (Table 2, entry 1). Both increase of amount of acrylate 4 (6 eq vs 4 eq) and $\mathrm{CH}_{3} \mathrm{CN}$ permitted to obtained compound 7 in better yield than that reported previously [18]. Modified aqueous conditions were tested with halogenated monophosphate 10 and triphosphate 11 and furnished the corresponding acrylated derivatives 15 and 16 in $35 \%$ and $4 \%$ yields, respectively (Table 2, entries 2 and 3). Application of the method to cytosine derivatives 12-14, having an amino group in position 4 , gave yields inferior to $16 \%$ (Table 2, entries 4-6). Starting from the 7-deazapurines 20 and 23 led to cross-coupled products 26 and 29 in $81 \%$ and $84 \%$ yields, respectively (Table 3, entries 1 and 4). Nucleotide derivatives 21, 22, 24 and 25 gave the corresponding acrylate analogues $27,28,30$ and 31 in $55 \%, 43 \%, 38 \%$ and $44 \%$ yields, respectively (Table 3 , entries $2,3,5$ and 6). In these conditions pyrimidine nucleotide derivatives gave poor yields or no target compounds probably due to substantial hydrolysis of the starting materials (Table 2, entries 2, 3, 5 and 6).

\section{Pd(II)-catalyzed Heck cross-coupling in $\mathrm{H}_{\mathbf{2}} \mathrm{O}$}

In 2014, for the first time, Len et al. reported a palladium catalyzed Heck cross-coupling reaction between 5iodo-2'-deoxyuridine and various acrylate derivatives using ligand-free conditions and assisted-microwaves in pure water [20]. Those new conditions allowed a totally aqueous access to antiviral BVDU. Heck cross-coupling of 5-iodo-2'-deoxyuridine (1) with various acrylate derivatives was carried out using $\mathrm{Pd}(\mathrm{OAc})_{2}(10 \mathrm{~mol} \%)$ alone in presence of $\mathrm{Et}_{3} \mathrm{~N}$ ( $2 \mathrm{eq}$ ) as base in $\mathrm{H}_{2} \mathrm{O}$ as solvent at $80^{\circ} \mathrm{C}$.

The reported method was very efficient with the shortest acrylate chains since it permit to furnish compounds 41 and 42 in 90\% yields (Table 4, entries 1 and 2). Compounds 7 and 43 in $45 \%$ yield even if the starting esters presented lipophilic properties (Table 4, entries 3 and 5). Shaugnessy and Hocek reported independently the obtention of 7 using aqueous conditions $\left(\mathrm{H}_{2} \mathrm{O} / \mathrm{CH}_{3} \mathrm{CN}\right)$ $[17,18]$. Isobutylacrylate has never been used in Heck cross-coupling reaction on nucleosides. It showed the same low solubility as butyl- and $t$-butylacrylate in water and original product 43 was isolated in $45 \%$ yields (Table 2, entry 4). Because the introduction of a heteroatom on the carbonated chain of the acrylate might allow access to more evolved compounds, authors undertook to examine the behavior of 2-chloro-, 2hydroxylethylacrylate 36 and 37 and its corresponding cyclic ether in our totally aqueous Heck conditions. The presence of the chlorine or of the oxygen atoms did not seem to change the lipophilic properties of the reactant. Consequently compounds 45,46 and 47 were isolated in the same range of yields (Table 4, entries $6-8)$. In order to modulate the structure, substitution 
of the ester by amido and cyano groups was studied. Application of the methodology allowed to isolate compounds 48 and 49 in respectively $60 \%$ and 51\% yields (Table 4, entries 9 and 10). Authors were able to obtain BVDU in sole water in three successive steps: free-ligand microwaves-assisted Heck cross-coupling of 1 with methylacrylate (32); hydrolysis and Hunsdiecker reaction. Finally, BVDU was obtained with a better total yield compared with the literature (56\% vs $31 \%$ [9]).

\section{Sonogashira cross-coupling}

Sonogashira cross-coupling reaction in aqueous solution was developed using both $\operatorname{Pd}(0)$ as catalyst in water or in $\mathrm{CH}_{3} \mathrm{CN} / \mathrm{H}_{2} \mathrm{O}$ and $\mathrm{Pd}(\mathrm{II})$ as a pre-catalyst only in $\mathrm{CH}_{3} \mathrm{CN} / \mathrm{H}_{2} \mathrm{O}$.

\section{$\mathrm{Pd}(0)$-catalyzed Sonogashira cross-coupling in $\mathrm{CH}_{3} \mathrm{CN} / \mathrm{H}_{2} \mathrm{O}$}

In 1990, Casalnuovo et al. undertook the Sonogashira coupling of unprotected nucleosides and nucleotides with acetylene derivatives [21]. Reactions were conducted in a mixture of $\mathrm{CH}_{3} \mathrm{CN} / \mathrm{H}_{2} \mathrm{O}$ (various proportion) as solvent using a self-made water-soluble $\mathrm{Pd}(0)$ complex (10 to 20 mol\%): $\mathrm{Pd}\left(\mathrm{PPh}_{2}\left(\mathrm{~m}-\mathrm{C}_{6} \mathrm{H}_{4} \mathrm{SO}_{3} \mathrm{M}\right)\right)_{3}$
$\left(\mathrm{M}=\mathrm{Na}^{+}, \mathrm{K}^{+}\right) \quad(10$ to $20 \mathrm{~mol} \%)$ in presence of $\mathrm{CuI}$ (0.2 eq to $0.5 \mathrm{eq})$ and $\mathrm{NEt}_{3}$ (2 eq to $\left.10 \mathrm{eq}\right)$.

5-Iodo-2'-deoxyuridine (1) was coupled to propargyltrifluoroacetamide as precursor of the propargyl amine in $95 \%$ yield (Table 5, entry 1 ). Starting from cytosine analogues 13 and 14, application of the method with variation of the concentration of reagents permitted to isolate the nucleotide analogues 51 and 52 in good to moderate yields (Table 5, entries 2 and 3). Authors demonstrated the versatility of their methodology as they obtained an alternative route to T-505 (52), part of a family of chain-terminating nucleotide reagents used in automated DNA sequencing and labeling (Table 5, entry 3). Increasing the amount of water $\left(\mathrm{CH}_{3} \mathrm{CN} / \mathrm{H}_{2} \mathrm{O}\right.$ 04:96 vs $\mathrm{CH}_{3} \mathrm{CN} / \mathrm{H}_{2} \mathrm{O}$ 1:1) led to lower yield (52\% vs $73 \%$ ).

\section{Pd(0)-catalyzed Sonogashira cross-coupling in $\mathrm{H}_{2} \mathrm{O}$}

In 2003, Burgess et al. successfully synthesized fluoresceinated thymidine triphosphate for polymerase mediated incorporation. Starting from the only water soluble triphosphate derivatives 11 and 53, Sonogashira coupling in presence of dye fragments furnished the target compounds 54-59 [22]. Compounds 54 and 55 were obtained in presence of $\left[\mathrm{Pd}\left(\mathrm{P}\left(\mathrm{C}_{6} \mathrm{H}_{4} \mathrm{SO}_{3} \mathrm{Na}\right)_{3}\right)_{4}\right]$

Table 5 Synthesis of 5-alkynyl pyrimidine analogues 50-52

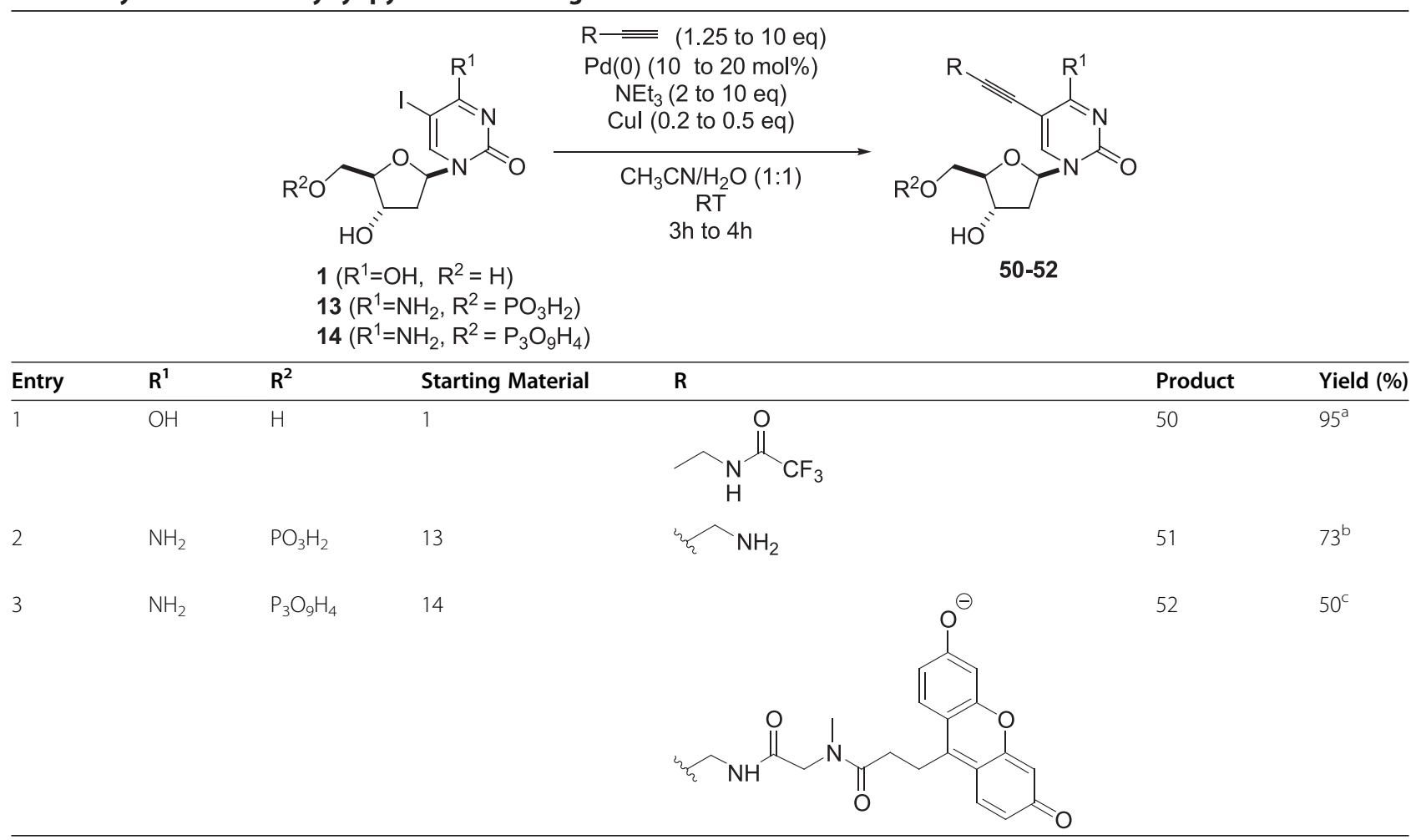

${ }^{\mathrm{a}} \mathrm{Pd}(0)$ (10 mol\%), $(\mathrm{R}=3 \mathrm{eq}), \mathrm{NEt}_{3}$ (2 eq), Cul (0.2 eq), $\mathrm{CH}_{3} \mathrm{CN} / \mathrm{H}_{2} \mathrm{O}$ (1:1), 4 h. ${ }^{\mathrm{b}} \mathrm{Pd}(0)(20 \mathrm{~mol} \%),(\mathrm{R}=10 \mathrm{eq}), \mathrm{NEt}{ }_{3}(10 \mathrm{eq}), \mathrm{Cul}(0.3 \mathrm{eq}), \mathrm{CH}{ }_{3} \mathrm{CN} / \mathrm{H}_{2} \mathrm{O}(1: 1)$, 3 h. ${ }^{C} \mathrm{Pd}(0)(20 \mathrm{~mol} \%), \mathrm{R}=(1.25 \mathrm{eq}), \mathrm{NEt}_{3}(10 \mathrm{eq}), \mathrm{Cul}(0.3 \mathrm{eq}), \mathrm{CH}_{3} \mathrm{CN} / \mathrm{H}_{2} \mathrm{O}(1: 1), 3 \mathrm{~h}$. 
(5 mol\%) as catalyst [23] at room temperature in $17 \%$ and $41 \%$ yields, respectively (Table 6 , entries 1 and 2). By using another source of $\left[\mathrm{Pd}\left(\mathrm{PPh}_{2}\left(3-\left(\mathrm{NaO}_{3} \mathrm{SC}_{6} \mathrm{H}_{4}\right)\right)_{4}\right]\right.$ (10 mol\%) [21], the authors reported the preparation of nucleotide analogues 56-59 in $17-42 \%$ yields (Table 6, entries 3-6). Starting from compound 11, a shorter reaction time was necessary compared with that starting from 2,3-dideoxy derivative 53. Although the authors did not explain the kinetic difference, it might be possible that the presence of an additional hydroxyl group induced higher solubility of 11 in water compared to the analog 53. Both methods furnished the target compounds 54-59 as triethylammonium salts after purification.

\section{Pd(II)-catalyzed Sonogashira cross-coupling in $\mathrm{CH}_{3} \mathrm{CN} / \mathrm{H}_{2} \mathrm{O}$}

In order to prepare unprotected purine nucleosides bearing oligopyridine ligands, Hocek et al. attempted Sonogashira cross-coupling reaction of 8-bromo-2'deoxyadenosine (60) and 7-deaaza-2'-deoxyadenosine (20) with 2,2'-bipyridine derivatives [24,25]. For this purpose, authors used $\mathrm{Pd}(\mathrm{OAc})_{2}$ as catalyst (5 mol\%), a water soluble ligand (TPPTS, $12.5 \mathrm{~mol} \%$ ), in presence of $\mathrm{CuI}(0.1 \mathrm{eq})$ and $\mathrm{Et}(\mathrm{iPr})_{2} \mathrm{~N}$ (10 eq) as base in a mixture of $\mathrm{CH}_{3} \mathrm{CN} / \mathrm{H}_{2} \mathrm{O}(1: 2)$ as solvent at $75^{\circ} \mathrm{C}$. However, under those conditions, complex mixtures were obtained. In this regard, the next goal of these authors was to prepare the corresponding $\mathrm{Ru}^{\mathrm{II}}$ complexes of

Table 6 Synthesis of 5-alkynyl pyrimidine analogues 54-59
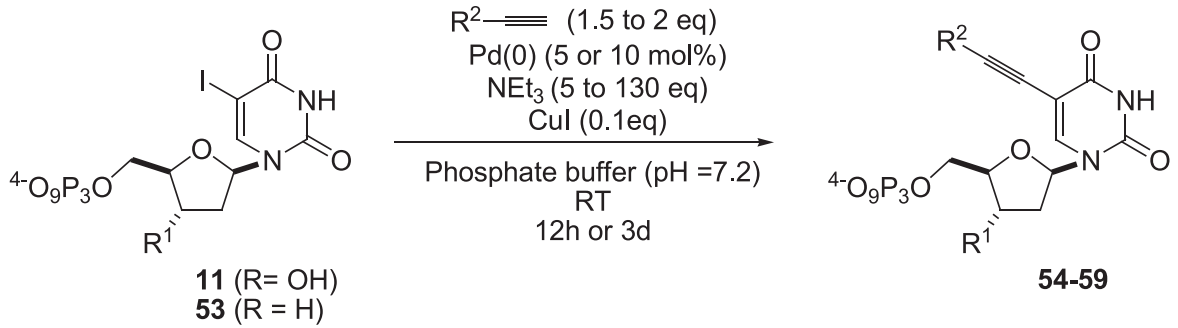

\begin{tabular}{|c|c|c|c|c|c|}
\hline Entry & $\mathrm{R}^{1}$ & Starting Material & $\mathrm{R}^{2}$ & Product & Yield (\%) \\
\hline 1 & $\mathrm{OH}$ & 11 & & 54 & $17^{a}$ \\
\hline 2 & $\mathrm{H}$ & 53 & & 55 & $41^{b}$ \\
\hline 3 & $\mathrm{OH}$ & 11 & & 56 & $17^{c}$ \\
\hline 4 & $\mathrm{H}$ & 53 & & 57 & $42^{d}$ \\
\hline 5 & $\mathrm{OH}$ & 11 & & 58 & $42^{e}$ \\
\hline 6 & $\mathrm{H}$ & 53 & & 59 & $26^{f}$ \\
\hline
\end{tabular}

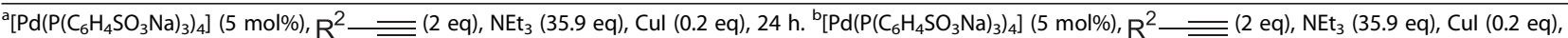
17 h. ${ }^{C}\left[\mathrm{Pd}\left(\mathrm{PPh}_{2}\left(3-\left(\mathrm{NaO}_{3} \mathrm{SC}_{6} \mathrm{H}_{4}\right)\right)_{4}\right](10 \mathrm{~mol} \%), \mathrm{R}^{2}=(1.5 \mathrm{eq}), \mathrm{NEt}_{3}(5 \mathrm{eq}), \mathrm{Cul}(0.1 \mathrm{eq}), 3 \mathrm{~d} .{ }^{\mathrm{d}}\left[\mathrm{Pd}^{2}\left(\mathrm{PPh}_{2}\left(3-\left(\mathrm{NaO}_{3} \mathrm{SC}_{6} \mathrm{H}_{4}\right)\right)_{4}\right]\left(10 \mathrm{~mol}^{2}\right), \mathrm{R}^{2}-\overline{\overline{=}}=(1.5 \mathrm{eq}), \mathrm{NEt}{ }_{3}\right.\right.$ (130 eq), Cul (0.1 eq), 12 h. ${ }^{e}\left[\mathrm{Pd}\left(\mathrm{PPh}_{2}\left(3-\left(\mathrm{NaO}_{3} \mathrm{SC}_{6} \mathrm{H}_{4}\right)\right)_{4}\right](10 \mathrm{~mol} \%), \mathrm{R}^{2}=(1.8 \mathrm{eq}), \mathrm{NEt}_{3}(130 \mathrm{eq}), \mathrm{Cul}(0.1 \mathrm{eq}), 3 \mathrm{~d} .{ }^{\mathrm{f}}\left[\mathrm{Pd}\left(\mathrm{PPh}_{2}\left(3-\left(\mathrm{NaO}_{3} \mathrm{SC}_{6} \mathrm{H}_{4}\right)\right)_{4}\right](10 \mathrm{~mol} \%)\right.\right.$, $\mathrm{R}^{2}=(1.5 \mathrm{eq}), \mathrm{NEt}_{3}(5 \mathrm{eq}), \mathrm{Cul}(0.1 \mathrm{eq}), 12 \mathrm{~h}$. 


Entry

the oligopyridine-nucleoside conjugates. The Sonogashira reactions of acetylenes $\mathrm{Ru}^{\mathrm{II}}$ building blocks were reacted with 8-bromo analogue 60 using the just above described methodology. The cross-coupling did not proceed very well due to the decomposition of the starting materials (Table 7) and only one compound, 61 , was obtained in $16 \%$ yield (Table 7 , entry 1 ). Starting from the 7 -deaaza purine 20 , modification of this method: $\mathrm{NEt}_{3}$, (10 eq) instead of $\mathrm{EtN}(\mathrm{iPr})_{2}(10 \mathrm{eq})$ permitted the synthesis of the target nucleoside analogues 63 and 64 bearing bipyridine ligands and their $\mathrm{Ru}(\mathrm{II})-$ complexes in position 7 in moderate yields (Table 8). Authors noticed that in both cases some byproducts were formed, probably due to the decomposition of the starting materials as already observed starting from compound 60 .

In 2007, Hocek et al. synthesized modified 2'-deoxyadenosine-5'-triphosphate and 2'-deoxyuridine-5'-triphosphate derivatives bearing ferrocene labels linked via a conjugate acetylene spacer [26]. Authors used a single-step Sonogashira aqueous-phase cross-coupling reaction starting from deprotected triphosphated deoxynucleosides 11 and 22 .

Table 8 Synthesis of Ru(II) complexes 63 and 64<smiles>Nc1ncnc2c1c(I)cn2C1C[C@H](O)[C@@H](CO)O1</smiles>

20

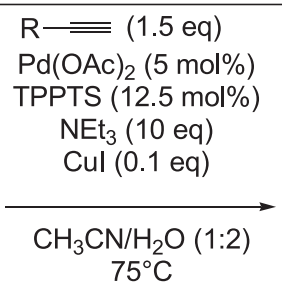

$75^{\circ} \mathrm{C}$

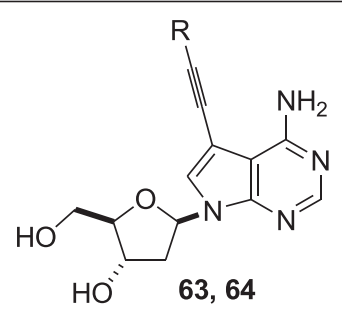

Product Yield (\%)

\begin{tabular}{llll}
\hline Entry & $\mathbf{R}$ & Product & Yield (\%) \\
\hline 1 & 63 & 47
\end{tabular}



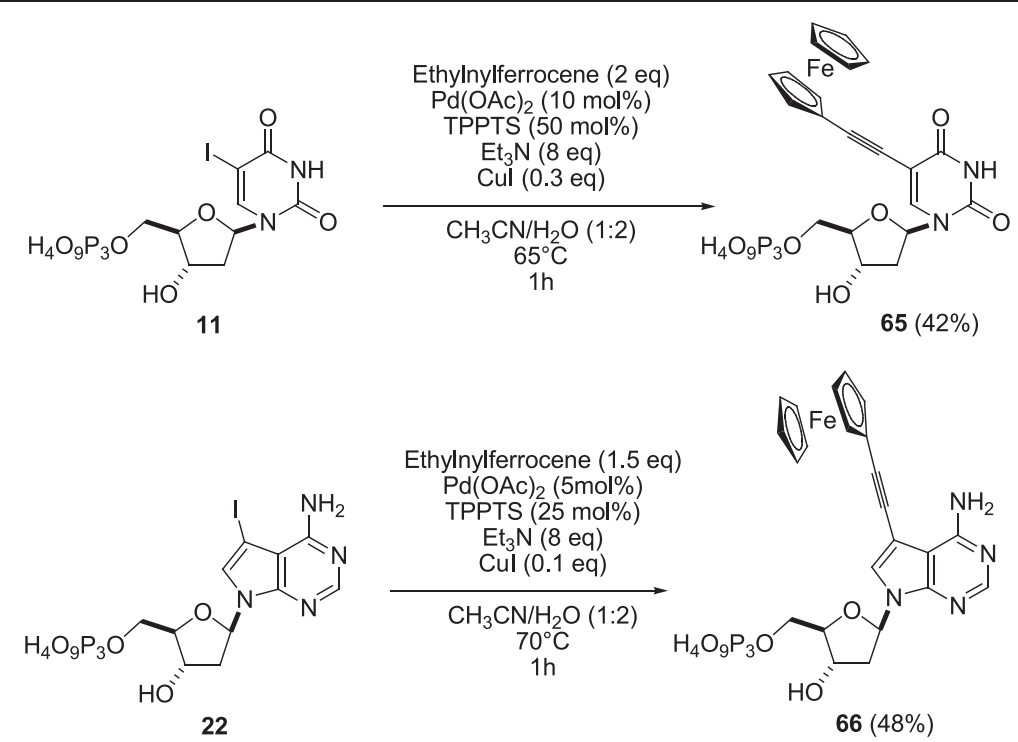

Scheme 2 Synthesis of ferrocene analogue 65 and 66 .

Reactions were performed in presence of $\mathrm{Pd}(\mathrm{OAc})_{2}$ (5 or $10 \mathrm{~mol} \%$ ), TPPTS (25 or $50 \mathrm{~mol} \%)$, CuI (10 or $30 \mathrm{~mol} \%$ ), $\mathrm{Et}_{3} \mathrm{~N}$ (8 eq) in a mixture $\mathrm{CH}_{3} \mathrm{CN} / \mathrm{H}_{2} \mathrm{O}(1: 2)$ as solvent. Variations of the amounts of reagents were not discussed by the authors. The cross-coupled products 65 and 66 were obtained in the same range of yields (42\% and 48\%) (Scheme 2).

In 2007, Hocek et al. used an aqueous Sonogashira reaction in order to couple different halonucleosides and their corresponding triphosphate with 4-(ethynyl)phenylalanine as amino acid moiety [27]. Thus, the nucleoside analogues 1 and 11 in presence of water-soluble catalytic system $\left(\mathrm{Pd}(\mathrm{OAc})_{2} / \mathrm{TPPTS}, 10 \mathrm{~mol} \% / 25 \mathrm{~mol} \%\right)$, triethylamine (7.2 eq) as base and $\mathrm{CuI}(0.1 \mathrm{eq})$ as additive in a mixture of $\mathrm{CH}_{3} \mathrm{CN} / \mathrm{H}_{2} \mathrm{O}$ (1:2) furnished the target nucleoside analogues 67 and 68 in $70 \%$ and $66 \%$ yields, respectively (Scheme 3).

Using very similar methodology, the authors also obtained the four phenylalanine derivatives 69-72 in good yields (61-74\%) (Figure 1).
After few modifications, the same group reported the synthesis of nucleoside and nucleotide conjugates of bile acids 73-87 using $\mathrm{Pd}(\mathrm{OAc})_{2}$ (5 mol\%), TPPTS (25 mol\%), $\mathrm{CuI}$ (0.1 eq), EtN(iPr) 2 (10 eq) in a mixture of $\mathrm{CH}_{3} \mathrm{CN} / \mathrm{H}_{2} \mathrm{O}$ (1:2) at $65-75^{\circ} \mathrm{C}$ for $0.25-1$ hour (Figure 2) [28].

In 2010, Shaughnessy et al. published their work on Sonogashira coupling of unprotected halonucleosides in aqueous solvent using water-soluble palladium catalysts [29]. First, a series of water-soluble phosphoranes (TPPTS, TXPTS, DCPES, $t \mathrm{Bu}$-Amphos) were screened for their ability to provide active palladium catalysts in a model Sonogashira coupling of unprotected 5-iodo-2'-deoxyuridine (1) and phenylacetylene. Authors showed the superior performance of TXPTS and concluded that increased steric demand of TXPTS (cone angle $206^{\circ}$ ) compared to TPPTS $\left(165^{\circ}\right)$ may account for the increased catalyst activity by promoting formation of low $\mathrm{LPd}^{0}$ active species. Compound 1 was then coupled with various alkynes using $\mathrm{Pd}(\mathrm{OAc})_{2}$ (10 mol\%), TXPTS (30 mol\%), CuI (0.1 eq) and triethylamine $(1 \mathrm{eq})$ at $65^{\circ} \mathrm{C}$ for 30 minutes in a mixture of

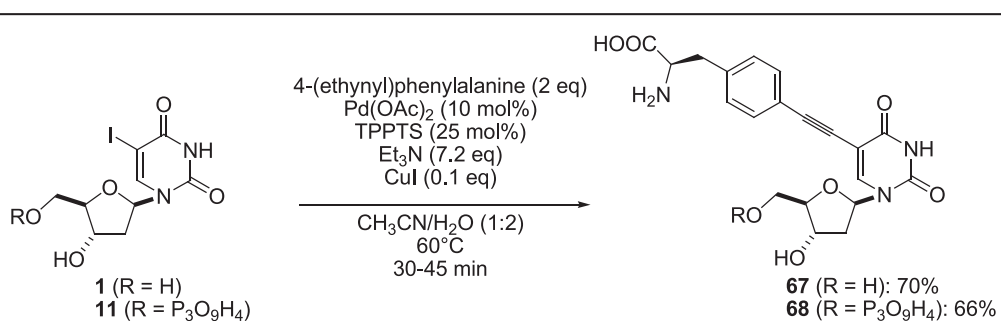

Scheme 3 Synthesis of phenylalanine analogues 67 and 68. 


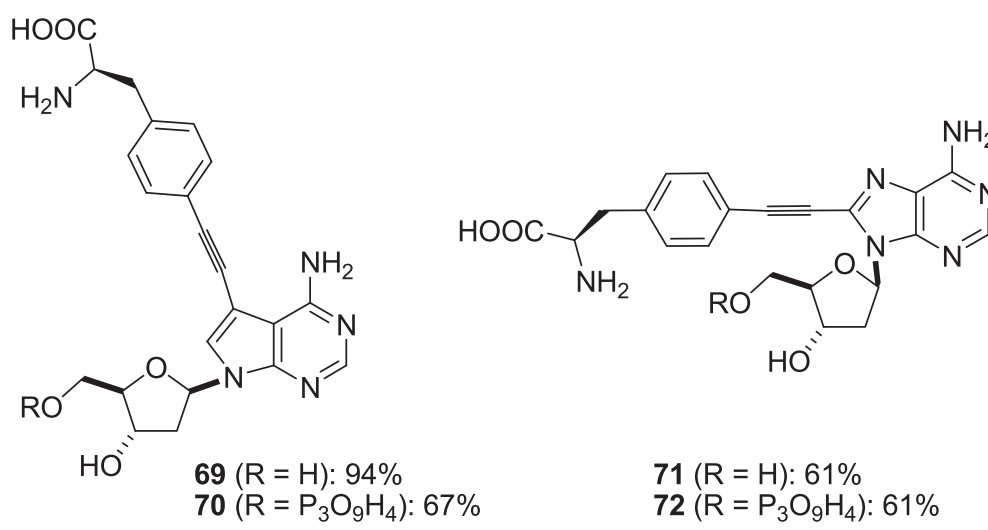

Figure 1 Synthesis of phenylalanine analogues 69-72.<smiles>[X]C(=O)CCC#Cc1cn([C@H]2C[C@H](O)[C@@H](CO)O2)c(=O)nc1N</smiles>

$73\left(X=O, R^{1}=O H, R^{2}=O H\right): 69 \%$

$74\left(X=O, R^{1}=H, R^{2}=O H\right): 35 \%$

$75\left(X=O, R^{1}=O H, R^{2}=H\right): 45 \%$

$76\left(X=N H, R^{1}=O H, R^{2}=O H\right): 69 \%$

$77\left(X=N H, R^{1}=H, R^{2}=O H\right): 65 \%$

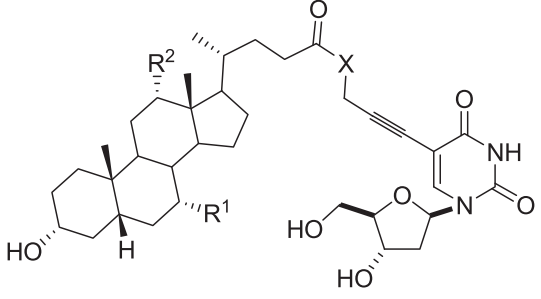

$83\left(X=N H, R^{1}=H, R^{2}=O H\right): 58 \%$

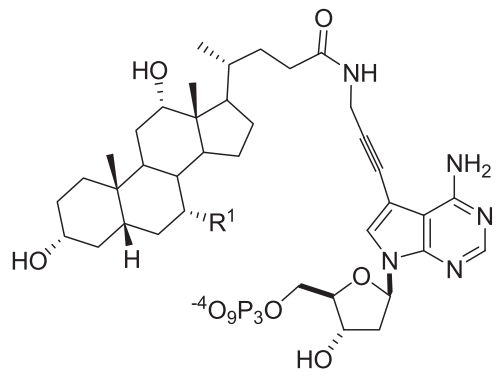

$86\left(R^{1}=O H\right): 32 \%$

$87\left(R^{1}=H\right): 53 \%$

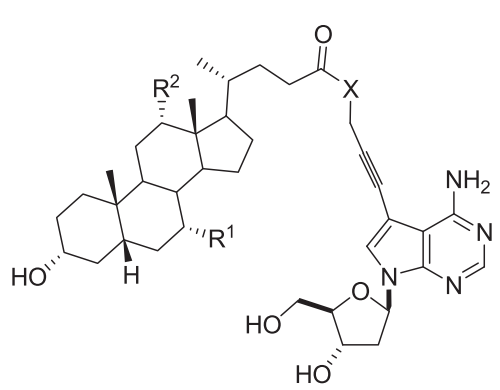

$78\left(X=O, R^{1}=O H, R^{2}=O H\right): 39 \%$ $79\left(X=O, R^{1}=H, R^{2}=O H\right): 88 \%$

$80\left(X=O, R^{1}=O H, R^{2}=H\right): 90 \%$ $81\left(X=N H, R^{1}=O H, R^{2}=O H\right): 66 \%$ $82\left(X=N H, R^{1}=H, R^{2}=O H\right): 61 \%$

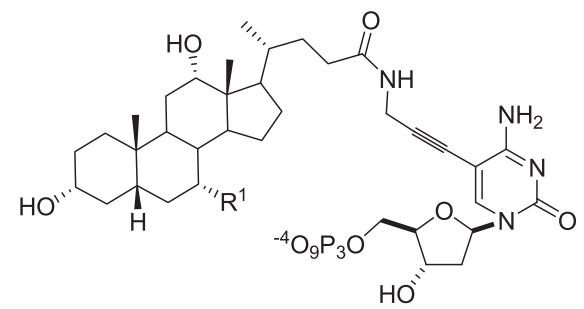

$84\left(\mathrm{R}^{1}=\mathrm{OH}\right): 44 \%$ $85\left(R^{1}=H\right): 57 \%$

Figure 2 Synthesis of alkynyl analogues 73-87. 
Table 9 Synthesis of 5-alkynyl nucleoside analogues 88-91

\begin{tabular}{llll} 
Entry \\
\hline 1
\end{tabular}

Table 10 Synthesis of 5-alkynyl nucleoside analogues 94-103

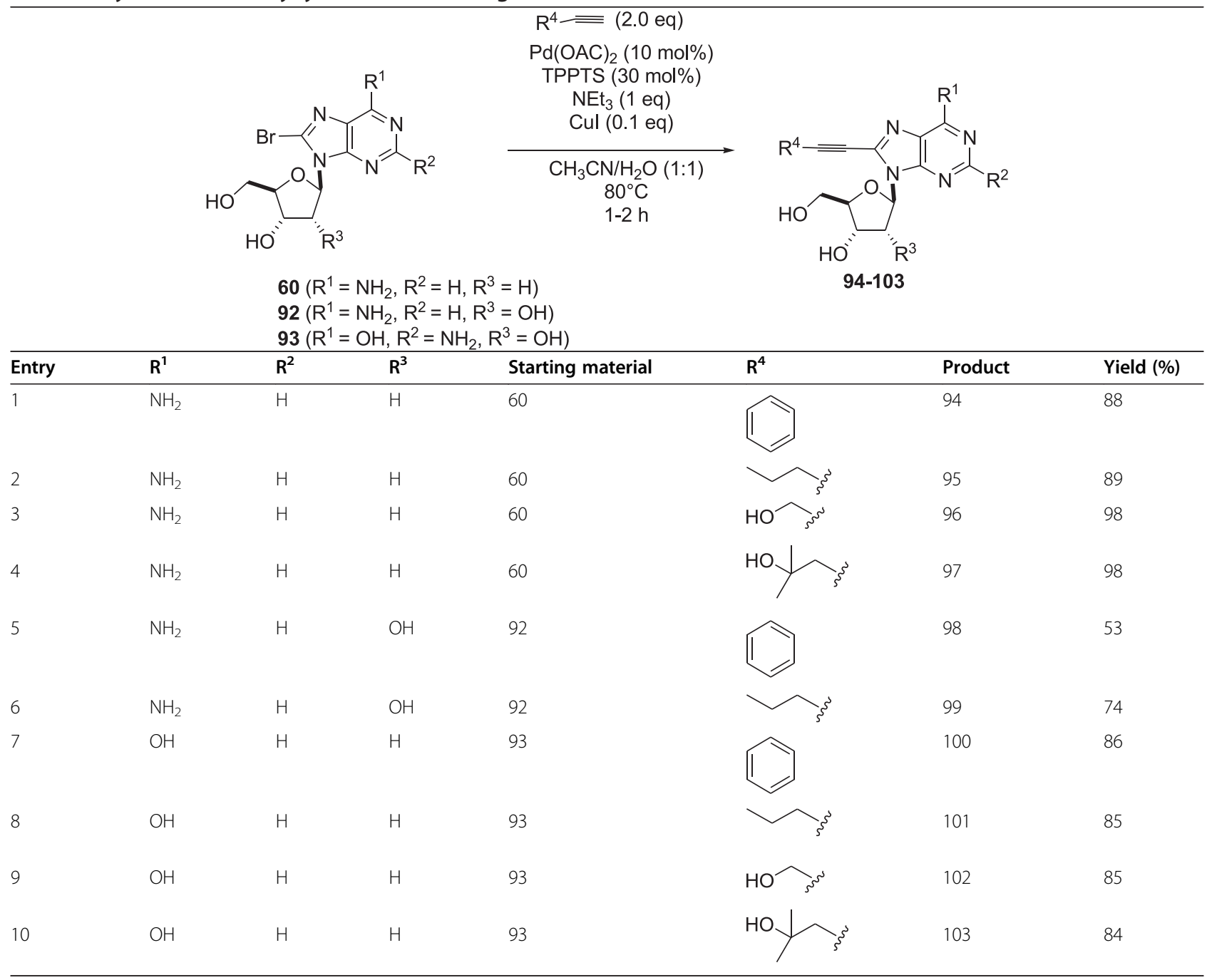


$\mathrm{CH}_{3} \mathrm{CN} / \mathrm{H}_{2} \mathrm{O}$ (1:1) to furnish the corresponding alkynes $88-91$ in $42-84 \%$ yields (Table 9). Authors noted that optimal yields were obtained when alkyne was added in three portions during the course of the reaction which limited the alkyne homocoupling.

In contrast to the high yield achieved with phenylacetylene (Table 8 , entry 1 ), reactions of compound 1 with simple alkyl-substituted alkynes gave lower yields (42\% and 55\% vs 71\%) of isolated products 89 and 90 (Table 9, entries 2 and 3). The more hindered alkyne permitted to isolate the desired cross-coupled compound 91 in $84 \%$ yield (Table 9, entry 4). In cases of the unhindered alkyne, authors noted the competitive formation of a well-known cyclized byproduct. Starting from purine analogues 60,92 and 93 , the authors used modified method $\left(80^{\circ} \mathrm{C}\right.$ vs $\left.65^{\circ} \mathrm{C}\right)$ to afford the corresponding alkynyl nucleoside analogues 94-103. The alkylynation conditions were further optimized for the couplings of 8-bromopurines [29]. Thus, 8bromo-2'-deoxyadenosine (60) and 8-bromo-2'-adenosine (92) were engaged with the previously described alkynes using, once again, $\mathrm{Pd}(\mathrm{OAc})_{2}$ (10 mol\%), TXPTS (30 mol\%), CuI (0.1 eq) and $\mathrm{NEt}_{3}(1 \mathrm{eq})$ in a mixture of $\mathrm{CH}_{3} \mathrm{CN} / \mathrm{H}_{2} \mathrm{O}$ (1:1). This time, reactions were performed at $80^{\circ} \mathrm{C}$ for $1-2$ hours to ensure a complete conversion of starting material (Table 9). Sonogashira couplings of 8-bromo-2'-deoxyadenosine (60) worked very well with both the phenylacetylene and the alkyl-substituted alkynes. Excellent yields of product were obtained with no formation of sideproducts (Table 10, entries 1-4). As usual the guanosine analogue 93 gave good but lower yields (Table 10, entries 7-10) and the nucleoside analogues having an hydroxyl group in the position 2' gave lower yields (Table 10, entries 5-6).

Two years later, Agrofoglio et al. developed a one-pot Sonogashira protocol to obtain substituted furopyrimidine nucleosides in aqueous conditions [30]. The conditions of the rection were optimized starting from 5-iodo-2'-deoxyuridine (1) and phenylacetylene. The desired furopyrimidine 104 was isolated in $47 \%$ yield following those conditions: $\mathrm{Na}_{2} \mathrm{PdCl}_{4}(2 \mathrm{~mol} \%)$, TXPTS (4 mol\%), CuI (0.4 eq), $\mathrm{NEt}_{3}$ (10 eq) in a mixture $\mathrm{CH}_{3} \mathrm{CN} / \mathrm{H}_{2} \mathrm{O}$ (1:1) as solvent. Then, the optimized conditions were applied to the coupling of various aromatic alkynes 104-110 (Table 11).

Table 11 Synthesis of furopyrimidine nucleoside analogues 104-110

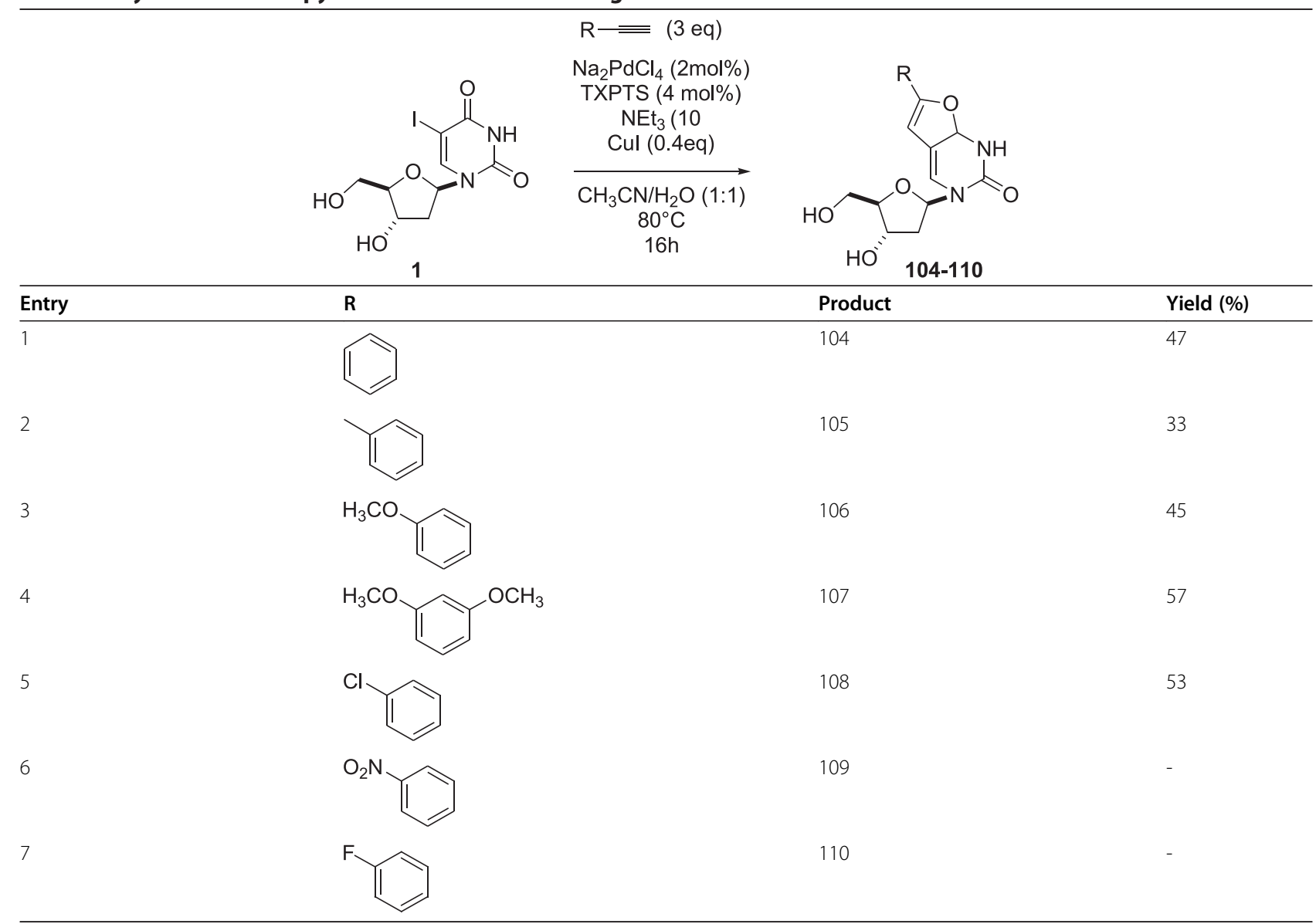


The expected bicyclic products 104-110 were isolated in moderate to good yields (33-57\%) with alkynes substituted with electron-rich aryl core (Table 11, entries 2-4). Concerning alkynes substituted with electron-poor aryl moiety, only one product was obtained (Table 11, entry 5). The bicyclic scaffold has already been observed before, but only as a byproduct [29].

\section{Conclusions}

The principal objective of this review was to describe the Heck and Sonogashira couplings of nucleosides in accordance with the 12 principles of green chemistry. To date, the majority of the works involved the synthesis (i) of alkenes in 5-position of pyrimidines and 7-position of 7-deazapurines and (ii) of alkynes in position 5 of pyrimidines, in position 7 of 7 - deazapurines and in position 8 position of purines. The usual starting materials used were 5-iodo, 7- and 8-bromo analogues. The review encompasses variations of the starting materials, alkene and alkyne, nature of the solvent, palladium source and ligand at either room temperature or higher temperature.

Concerning the Heck cross-couplings, only palladium $\mathrm{Pd}(\mathrm{II})$ such as $\mathrm{Na}_{2} \mathrm{PdCl}_{4}(80 \mathrm{~mol} \%)$ and $\mathrm{Pd}(\mathrm{OAc})_{2}$ (5$10 \mathrm{~mol} \%$ ) was used. Most of the reactions were realized in presence of TPPTS as ligand in a mixture of $\mathrm{CH}_{3} \mathrm{CN} /$ $\mathrm{H}_{2} \mathrm{O}$ and in sole water. Using these procedures, the yields were low to good (4-98\%). It is noteworthy that recent results of Len's group starting from 5-iodo-2'-deoxyuridine furnished, in pure water, in presence of $\mathrm{Pd}(\mathrm{OAc})_{2}$ (10 mol\%) and $\mathrm{NEt}_{3}$ without any ligand at $80^{\circ} \mathrm{C}$ under microwave irradiation the heterocyclic targets in $35-90 \%$ yields.

Concerning the Sonogashira cross-couplings, the reported procedures were similar (alkyne, $\mathrm{NEt}_{3}, \mathrm{CuI}$ ) excepted for the nature of the palladium $(\operatorname{Pd}(0)$ and $\mathrm{Pd}(\mathrm{II}))$ and the nature of the solvent $\left(\mathrm{CH}_{3} \mathrm{CN} / \mathrm{H}_{2} \mathrm{O}\right.$ and sole water). $\operatorname{Pd}(0)$ was used in aqueous media or in pure water while $\mathrm{Pd}(\mathrm{II})$ was used only in a mixture of $\mathrm{CH}_{3} \mathrm{CN} / \mathrm{H}_{2} \mathrm{O}$. The yields of the target nucleoside analogues were comprised between $16-98 \%$. It is noteworthy that nucleotide analogues having either mono- and triphosphate as starting material afforded the corresponding cross-coupling adducts in presence of $\mathrm{Pd}(0)$ in water or in presence of $\mathrm{Pd}(\mathrm{II})$ in $\mathrm{CH}_{3} \mathrm{CN} / \mathrm{H}_{2} \mathrm{O}$.

In the future, the Heck and Sonogashira cross-coupling reactions of nucleoside analogues, in ligand-free conditions, as reported by Len with recycling of the catalytic system will open a new avenue for the green chemistry applied to heterocyclic chemistry.

\section{Competing interests}

The authors declare that they have no competing interests.

\section{Authors' contributions}

$\mathrm{GH}$ searched the current literature and drafted the manuscript. CL drafted the introduction and conclusion. Both authors contributed equally to the readings and corrections. Both authors read and approved the final manuscript.

Received: 7 October 2014 Revised: 12 December 2014 Accepted: 13 February 2015

Published online: 19 March 2015

\section{References}

1. Lebreton J, Escudier JM, Arzel L, Len C. Synthesis of bicyclonucleosides having a C-C bridge. Chem Rev. 2010;110:3371-418.

2. Len C, Mondon M, Lebreton J. Synthesis of cyclonucleosides having a C-C bridge. Tetrahedron. 2008;64:7453-75.

3. Len C, Mackenzie G. Synthesis of 2',3'-didehydro-2',3'-dideoxynucleosides having variations at either or both of the $2^{\prime}$ - and $3^{\prime}$-positions. Tetrahedron. 2006:62:9085-107.

4. Wright K. AIDS Therapy. First tentative signs of therapeutic promise. Nature 1986:323:283.

5. Agrofoglio LA, Gillaizeau I, Saito Y. Palladium-assisted routes to nucleosides Chem Rev. 2003;103:1875-916.

6. Fairlamb IJS. Regioselective functionalisation of unsaturated halogenated nitrogen, oxygen and sulfur heterocycles by Pd-catalysed cross-coupling and direct arylation processes. Chem Soc Rev. 2007;36:1036-45.

7. Hervé G, Sartori G, Enderlin G, Mackenzie G, Len C. Palladium-catalyzed Suzuki reaction in acqueous solvents applied to unprotected nucleosides and nucleotides. RSC Adv. 2014:4:18558-94.

8. De Clercq E, Descamps J, De Somer P, Barr PJ, Jones AS, Walker RT. (E)-5-(2-Bromovinyl)-2'-deoxyuridine: A potent and selective anti-herpes agent. Proc Natl Acad Sci U S A. 1979;76:2947-51.

9. Ashwell M, Jones AS, Kumar A, Sayers JR, Walker RT, Sakuma T, et al. The synthesis and antiviral properties of (E)-5- (2-bromovinyl)-2'-deoxyuridinerelated compounds. Tetrahedron. 1987;43:4601-8.

10. Kuwahara M, Sugimoto N. Molecular evolution of functional nucleic acids with chemical modifications. Molecules. 2010;15:5423-44.

11. Hollenstein M. Nucleoside triphosphates - Building blocks for the modification of nucleic acids. Molecules. 2012;17:16569-3591.

12. Sartori G, Enderlin G, Hervé G, Len C. Highly effective synthesis of C-5substituted 2'-deoxyuridine using Suzuki-Miyaura cross-coupling in water. Synthesis. 2012;44:767-72.

13. Sartori G, Hervé G, Enderlin G, Len C. New efficient approach of ligand-free Suzuki-Miyaura reaction applied to 5-iodo-2'-deoxyuridine in neat water. Synthesis. 2013:45:330-3.

14. Gallagher-Duval S, Hervé G, Sartori G, Enderlin G, Len C. Improved microwave-assisted ligand-free Suzuki-Miyaura cross-coupling of 5-iodo-2'deoxyuridine in pure water. New J Chem. 2013;37:1989-95.

15. Enderlin G, Sartori G, Hervé G, Len C. Synthesis of 6-aryluridines via SuzukiMiyaura cross-coupling reaction at room temperature under aerobic ligand-free conditions in neat water. Tetrahedron Lett. 2013;54:3374-7.

16. Sakthivel K, Barbas III CF. Expanding the potential of DNA for binding and catalysis: Highly Functionalized dUTP Derivatives that are substrates for thermostable DNA polymerase. Angew Chem Int Ed. 1998;37:2872-5.

17. Lee SE, Sidorov A, Gourlain T, Mignet N, Thorpe SJ, Brazier JA, et al. Enhancing the catalytic repertoire of nucleic acids: a systematic study of linker length and rigidity. Nucleic Acids Res. 2001;29:1565-73.

18. Cho JH, Shaughnessy KH. Aqueous-phase Heck couplings of 5-iodouridine and alkenes under phosphine-free conditions. Synlett. 2011;20:2963-6.

19. Dadová J, Vidláková P, Pohl R, Havran L, Fojta M, Hocek M. Aqueous Heck cross-coupling preparation of acrylate-modified nucleotides ans nucleoside triphosphates for polymerase synthesis of acrylate-labeled DNA. J Org Chem. 2013;78:9627-37.

20. Hervé G, Len C. First ligand-free, microwaves-assisted, Heck cross-coupling reaction in sole water on nucleoside - Application to the synthesis of antiviral BVDU. RSC Adv. 2014:4:46926-9.

21. Casalnuovo AL, Calabrese JC. Palladium-catalyzed alkylynations in aqueous media. J Am Chem Soc. 1990;112:4324-30.

22. Thoresen LH, Jiao GS, Haaland WC, Metzker ML. Rigid, conjugated, fluoresceinated thymidine triphosphates: syntheses and polymerase mediated incorporation into DNA analogues. Chem Eur J. 2003;9:4603-10. 
23. Bong DT, Ghadiri MR. Chemoselective Pd(0)-catalyzed peptide coupling in water. Org Lett. 2011;16:2509-11.

24. Vrábel M, Pohl R, Klepetárvá B, Votruba I, Hocek M. Synthesis of 2'deoxyadenosine nucleosides bearing bipyridine-type ligands and their Ru-complexes in position 8 trough cross-coupling reactions. Org Biomol Chem. 2007;5:2849-57.

25. Brázdilová $\mathrm{P}$, Vrábel M, Pohl R, Pivoňková H, Havran L, Hocek M, et al Ferrocenylethynyl derivatives of nucleosides triphosphates: synthesis, incorporation, electrochemistry, and bioanalytical applications. Chem Eur J. 2007;13:9527-33

26. Čapek P, Cahová H, Pohl R, Hocek M, Gloeckner C, Marx A. An efficient method for the construction of functionalized DNA bearing amino acid group through cross-coupling reactions of nucleoside triphophates followed by primer extension or PCR. Chem Eur J. 2007;13:6196-203.

27. Vrábel M, Pohl R, Votruba I, Sajadi M, Kovalenko SA, Ernsting NP, et al. Synthesis and photophysical properties of 7-deaaza-2'-deoxyadenosines bearing bupyridine ligands and their Ru(II)-complexes in position 7. Org Biomol Chem. 2008;6:2852-60.

28. Kalachova L, Pohl R, Hocek M. Synthesis of 2'-deoxyuridine and 2'deoxycytidine nucleosides bearing bipyridine and terpyridine ligands at position 5. Synthesis. 2009;1:105-12

29. Cho JH, Prickett CD, Shaughnessy KH. Efficient Sonogashira coupling of unprotected halonucleosides in aqueous solvents using water-soluble palladium catalysts. Eur J Org Chem. 2010;19:3678-83.

30. Fresneau N, Hiebel MA, Agrofoglio LA, Berteina-Raboin S. One-pot Sonogashira-cyclization protocol to obtain substituted furopyrimidine nucleosides in aqueous conditions. Tetrahedron Lett. 2012;53:1760-3.

\section{Publish with ChemistryCentral and every scientist can read your work free of charge \\ "Open access provides opportunities to our colleagues in other parts of the globe, by allowing anyone to view the content free of charge." \\ W. Jeffery Hurst, The Hershey Company. \\ - available free of charge to the entire scientific community \\ - peer reviewed and published immediately upon acceptance \\ - cited in PubMed and archived on PubMed Central \\ - yours - you keep the copyright \\ Submit your manuscript here: \\ http://www.chemistrycentral.com/manuscript/ O Chemistry Central}

